\title{
Observation of a Deformity (Anophthalmia) in the Critically Endangered Amboli Toad (Xanthophryne tigerina) from the Western Ghats of India
}

Anish Pardeshi

Pune-411042, Maharashtra, India (anishpardeshi103@gmail.com)

$A^{n}$

mphibians often are susceptible to environmental influences due to distinctive characteristics that include permeable skin, shell-less eggs, and a multifaceted life-cycle that incorporates both aquatic and terrestrial phases (Hippargi et al. 2010). Deformities, however, are usually expressed only in the presence of unique or exceptional environmental pollutants or developmental disruptors, thereby rendering amphibians potential "bioindicators" of environmental health (Blaustein 1994). Reports on amphibian deformities have been available since the 18th Century (Vallisneri 1733), yet global scientific attention has only been focused on the possibility of widespread declines in amphibian populations since the early 1980 s (Carey and Bryant 1995). Concerns about amphibians further heightened when Schmidt (1997) documented the 1995 Minnesota farm incident involving the discovery of widespread malformations in frogs.

Few deformities have been recorded in Indian amphibians. Gurushankara et al. (2007) described morphological abnormalities in natural populations of four common frog species inhabiting the agro-ecosystems of the central Western Ghats. The morphological abnormalities recorded in that study included abnormal limbs (hemimelea: short tibiafibula; brachydactyly: short toe; ectrodactyly: missing digit; ectromelea: incomplete limb with missing lower portion, and tumor on the femur), eyes (anophthalmia: missing eye and microphthalmea: small eye), and a bulging abdomen. Hippargi et al. (2010) observed developmental abnormalities in a wild-caught Asian Toad (Duttaphrynus melanostictus) from Nagpur, Maharashtra; Modak et al (2013) reported a Ferguson's Toad (Duttaphrynus scaber) with abnormal toes; and Ganesh and Arumugam (2015) observed anophthalmia in a Sreeni's Golden Frog (Indosylvirana sreeni) in the southern Eastern Ghats.

During a field survey at 2026 h on 20 June 2016, I observed an Amboli Toad (Xanthophryne tigerina) exhibiting anophthalmia (Fig. 1) in the vicinity of the village of Amboli.
The left eye of that individual was totally missing. I saw no traumatic morphological aberrations, suggesting that the eye
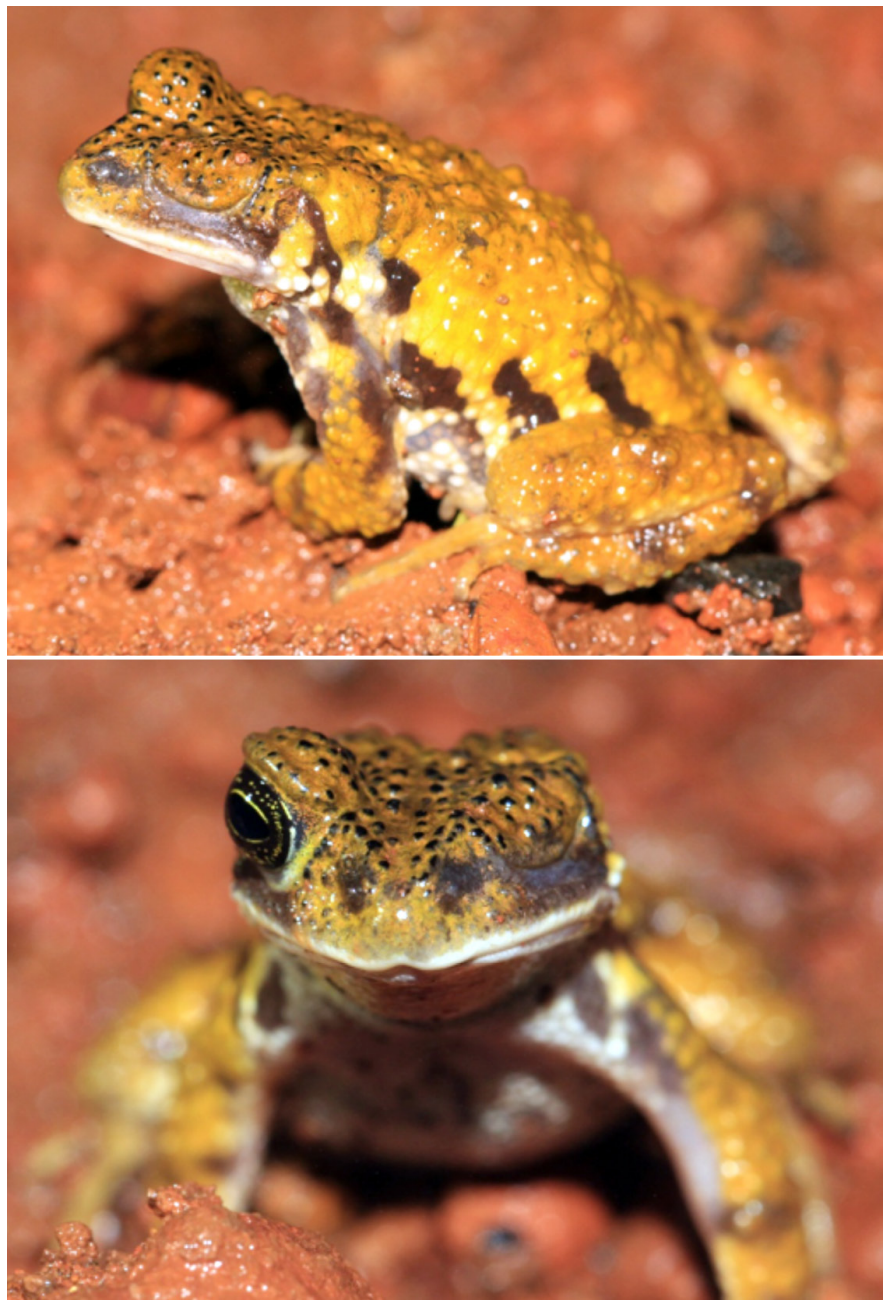

Fig. 1. An Amboli Toad (Xanthophryne tigerina) with anophthalmia (missing left eye) from the vicinity of the village of Amboli in the northern Western Ghats of India. Photographs by Kaka Bhise. 
loss was not predator-mediated, but from a malformation, i.e., anophthalmia. Amboli $\left(15^{\circ} 57^{\prime} \mathrm{N}, 73^{\circ} 59^{\prime} \mathrm{E}\right)$ is located on the crestline of the northern Western Ghats, Sindhudurg District, in the state of Maharashtra, India (elevation $720 \mathrm{~m}$ ). The average annual temperature is $23.9^{\circ} \mathrm{C}$ and about 3,589 $\mathrm{mm}$ of precipitation falls annually. Vegetation around Amboli comprises semi-evergreen and moist deciduous forests intermixed with some evergreen forest patches (Jog 2009). The Amboli Toad is listed as Critically Endangered on the IUCN Red List because it is known only from the type locality, (Amboli, Maharashtra state in the Western Ghats of India; Biju et al. 2009) and its area of occupancy is estimated to be less than $10 \mathrm{~km}^{2}$ (IUCN SSC Amphibian Specialist Group 2011).

\section{Acknowledgements}

I thank Kaka Bhise for providing photographs of the Amboli Toad with anophthalmia. I also thank Rutuja Pardeshi for useful comments that improved the manuscript.

\section{Literature Cited}

Biju, S.D., I. Van Bocxlaer, V.B. Giri, S.P. Loader, and F. Bossuyt. 2009. Two new endemic genera and a new species of toad (Anura: Bufonidae) from the Western Ghats of India. BMC Research Notes 2: 241.
Blaustein, A.R. 1994. Chicken Little or Nero's fiddle? A perspective on declining amphibian populations. Herpetologica 50: 85-97.

Carey, C. and C.J. Bryant. 1995. Possible interrelations among environmental toxicants, amphibian development, and decline of amphibian populations. Environmental Health Perspectives 103(suppl. 4): 13-17.

Ganesh, S.R. and M. Arumugam. 2015. Natural history and distribution notes on the Sreeni's Golden Frog (Indosylvirana sreeni) in the southern Eastern Ghats, peninsular India. Alytes 32: 59-65.

Gurushankara, H.P., S.V. Krishnamurthy and V. Vasudev. 2007. Morphological abnormalities in natural populations of common frogs inhabiting agroecosystems of central Western Ghats. Applied Herpetology 4: 39-45.

Hippargi, R.V., L.J. Harkare, and A.D. Garg. 2010. Observations on developmental abnormalities in a wild specimen of Duttaphrynus melanostictus (Schneider, 1799) from Nagpur, Maharashtra, India. Frogleg 14: 16-20

IUCN (International Union for Conservation of Nature). 2011. IUCN Red List of Threatened Species (ver. 2011.1). (http://www.iucnredlist.org).

IUCN SSC Amphibian Specialist Group. 2011. Xanthophryne tigerina. The IUCN Red List of Threatened Species 2011: e.T189700A8763964 (http://dx.doi. org/10.2305/IUCN.UK.2011-1.RLTS.T189700A8763964.en).

Jog, S.K. 2009. Sahyadris - flora and ethnobotany. Unpublished report, University of Texas at Tyler, Tyler, Texas, USA.

Modak, N., A. Padhye, and A. Bayani. 2013. A report of Duttaphrynus scaber Schneider (1799) (Anura: Bufonidae), with abnormal toes, from Gavase, Kolhapur District, Maharashtra. Ela Journal 2(3): 2-6.

Schmidt, C.W. 1997. Amphibian deformities continue to puzzle researchers. Environmental Science \& Technology 31: 324-326.

Vallisneri, A. 1733. Opere fisico-mediche stampate e manoscritte del Kavalier Antonio Vallisneri raccolte da Antonio suo figliuolo, corredate duna Prefazione in genere sopra tutte, e d'una in particolare sopra il Vocabolario della Storia Naturale. Tomo secondo. Appresso Sebastiano Coleti, Venezia. 